\title{
Immune Response of Rainbow Trout (Oncorhynchus mykiss) to Selected Antigens of Yersinia ruckeri
}

\author{
Unal Ispir, H. Bayram Gokhan, Mikail Ozcan, Mustafa Dorucu, Naim Saglam \\ Firat University, Fisheries Faculty, Department of Fish Diseases, Elazig, Turkey
}

Received January 3, 2008

Accepted October 1, 2008

\begin{abstract}
In this study, effects of Yersinia ruckeri antigens on the immune mechanisms of rainbow trout (Oncorhynchus mykiss) were examined. The weight of the 120 fish used in this study was 20-30 g. After injecting $1 \mathrm{mg}$ of formalin-inactivated whole cells (FKC) and O-antigen (Ag-O) intraperitoneally, blood was taken from the caudal vein of anaesthetized fish and metabolic activity of leukocytes (Nitroblue tetrazolium (NBT) activities), phagocytic activity (PA), phagocytic index (PI), serum protein and serum total immunoglobulin (TIg) levels were determined on day 30 after the first immunization. The same procedure was conducted in the control group. In all the experimental groups, considerable increases in the immune indicators were found and significant differences detected between the control and experimental groups $(p<0.05)$. Metabolic activity of leukocytes decreased significantly $(p<0.05)$ during the following treatment with antigens compared to the control fish group.
\end{abstract}

Rainbow trout, antigen, phagocytosis, Yersinia ruckeri, immunity

Yersinia ruckeri is the causative agent of enteric redmouth disease (ERM). An infectious disease which produces high mortalities and severe economic losses on fish farms, particularly in rainbow trout and atlantic salmon. Yersinia ruckeri is a gramnegative rod which is a water organism first described in 1955 (Ewing et al. 1978). However, in the last two decades the disease has become established in fish farmed in many countries in Europe and the world (Tobback et al. 2007).

ERM is characterized by the presence of congestive or haemorrhagic zones in various tissues and organs, particularly around the mouth and the intestines. Its mode of transmission has been related to wild or farmed carrier fish and other putative vectors, such as aquatic invertabrates and birds (Willumsen 1989).

Yersinia ruckeri is an opportunistic pathogen commonly present in the waters; antibiotic treatments would be useless as they induce antibiotic resistance. Consequently, the best way to deal with the infection is vaccination. To date, excellent progress has been made with the control of infections caused by Yersinia ruckeri. In particular, ERM may be controlled effectively by inactivated whole cell vaccines (Ross et al. 1966), which are available commercially and are considered to be extremely successful (Tebbit et al. 1981). However, there are only limited studies on immunological variables after vaccination. Previously vaccination experiments were performed on fish, limiting with survival ability. The aim of this study was to lay out the basis to evaluate the formalin killed cells (FKC) and O-antigen (Ag-O) preparations of Yersinia ruckeri on the cellular and humoral immune response of rainbow trout (Oncorhynchus mykiss).

\section{Materials and Methods}

Fish

Healthy rainbow trout $(20-30 \mathrm{~g}, \mathrm{n}=120)$ were obtained from a commercial fish farm. Fish were acclimatized to laboratory conditions for 2 weeks at $14 \pm-1^{\circ} \mathrm{C}$ and fed daily a commercial diet (Ecobio, Turkey). The experiment was carried out with three replicates per treatment.

Address for correspondence:

Unal ISPIR

Rizaiye Mah. Hastane Sok.

No: $35 / 323200$

Elazig, TURKEY 
Preparation of antigens

Yersinia ruckeri was pre-cultured in Tryptic Soy Agar (TSA) at $22{ }^{\circ} \mathrm{C}$ for $24 \mathrm{~h}$, then inoculated in the same broth and incubated at $22{ }^{\circ} \mathrm{C}$ for $24 \mathrm{~h}$. For this bacterial culture, two antigens consisting of formalin killed cells (FKC) and O-Antigen (Ag-O) were prepared. To obtain the FKC preparation, a part of broth culture was added with $0.7 \%$ formalin to inactivate the bacteria and incubated at $22{ }^{\circ} \mathrm{C}$ for $48 \mathrm{~h}$; then the cells were washed three times by centrifugation at $10.000 \times g$ for $30 \mathrm{~min}$ and stored at $4{ }^{\circ} \mathrm{C}$ until used.

The Ag-O was obtained following the technique described by Edwards and Ewing (1972). Yersinia ruckeri cells were pelleted by centrifugation at $1600 \times g$ for $25 \mathrm{~min}$ at $4{ }^{\circ} \mathrm{C}$, suspended at $10 \%$ PBS, heat-killed by placing in a boiling water bath for $60 \mathrm{~min}$, and then centrifuged twice at $8,000 \times g$ for $10 \mathrm{~min}$ at $4{ }^{\circ} \mathrm{C}$. The pellet was resuspended in ethanol at room temperature for $24 \mathrm{~h}$. The suspension was centrifuged at $3000 \times g$ for $10 \mathrm{~min}$ and washed twice in acetone. The pellet was dried overnight at room temperature and crushed. The antigen-O was stored at $4{ }^{\circ} \mathrm{C}$ until required for use.

Immunization of rainbow trout

Two groups of fish (40 fish per group) were injected intraperitoneally (i.p.) with $0.1 \mathrm{ml}$ of antigen preparation containing $1.0 \mathrm{mg}$ FKC or Ag-O. The control group (40 fish) was injected with $0.1 \mathrm{ml}$ PBS. Fish were reimmunized i.p. by injection with antigens 15 days after the first immunization.

\section{Sampling procedure}

The rainbow trout from each group were bled by cardiac puncture 30 days after the first immunization.

Immunological assays

Total plasma protein was measured by Biuret method (Kwapinski 1965). Total plasma immunoglobulin was measured as previously described by Siwicki and Anderson (1993). First Ig were separated from plasma by precipitation with polyethylene glycol and remaining protein in the supernatant was assayed. That amount was subtracted from the total protein to give total Ig.

In vitro phagocytosis was performed in immunized and control fish to evaluate cellular immunity. Phagocytic activity was measured according to the method described by Siwicki and Anderson (1993). The heparinized blood was immediately used for the phagocytic assay. Briefly, $1 \times 10^{7}$ cels Yersinia ruckeri $0.1 \mathrm{ml}$ of PBS were added to $0.1 \mathrm{ml}$ of blood samples in a microplate and incubated for $30 \mathrm{~min}$ after through mixing in the well. After incubation, the plate was mixed gently, and $0.05 \mathrm{ml}$ of this suspension was smeared on the glass slide. After airdrying, the smears were fixed in ethanol and stained with Giemsa (7\%). The phagocytic cells and phagocytosed bacteria were counted. Phagocytic activation (PA) and phagocytic index (PI) were determined by enumerating 100 phagocytes per slide under a microscope. The mean of the slides was calculated as below;

PA: (Number of phagocytic cells with engulfed bacteria/number of phagocytes) $\times 100$

PI: (Number of engulfed bacteria/phagocytic cells).

For the detection of NBT activity by spectrophotometric assay, $0.1 \mathrm{ml}$ of blood was put into a microtitre plate well, and then an equal amount of $0.2 \%$ NBT solution (nitroblue tetrazolium, Sigma) in PBS was added. After incubation at room temperature for $30 \mathrm{~min}, 0.05 \mathrm{ml}$ of the NBT-blood cell suspension was removed and added to a glass tube containing $1.0 \mathrm{ml}$ of $\mathrm{N}, \mathrm{N}$ dimethyl formamide. After centrifugation, reading in a spectrophotometer at $620 \mathrm{~nm}$ in a $1.0 \mathrm{ml}$ cuvette was performed.

Statistical analysis

Differences in immunological indicators between experimental and control fish were analyzed by Student's $t$-test using Minitab Statistical Software Release 10. Means and standard deviations (SD) were calculated for each variable measured. Differences were considered significant at $p<0.05$.

\section{Results}

The plasma protein and total plasma immunoglobulin levels recorded in the experimental and control groups are shown in Figs 1 and 2. Higher protein levels were obtained in rainbow trout immunized by $\mathrm{Ag}-\mathrm{O}$ preparations after the injection compared to the control group $(p<0.05)$. The total Ig level in the FKC and Ag-O injected groups were significantly different $(p<0.05)$ than in the control group (Fig. 2).

Metabolic activity of leukocytes varied among individual fish from each group. No significant differences in this variable were found between vaccinated and unvaccinated fish (Fig. 3).

The results of in vitro total blood phagocytosis are shown in Figs 4 and 5. In the blood leukocytes isolated from the FKC and Ag-O treatment groups an increase in phagocytic activity was found. Although there were only small differences, the experimental group showed a significant $(p<0.05)$ increase in phagocytic ability (Fig. 5). Comparison of 
the PA and PI of the fish on treatments FKC and Ag-O showed no significant differences $(p>0.05)$.

Protein levels

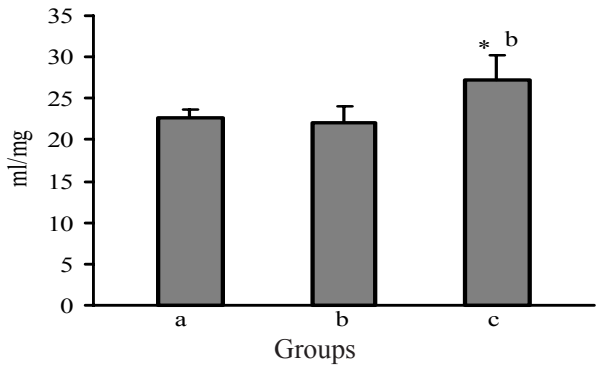

Fig. 1. Total protein level of serum from rainbow trout injected with PBS and antigens. a: Control group, b: FKC, c: Ag-O. * $p<0.05$

Metabolic activity of leukocytes

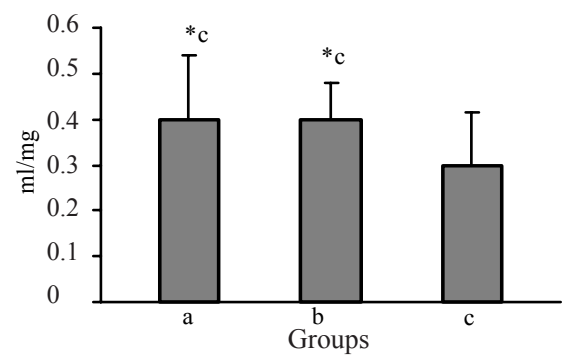

Fig. 3. Metabolic activity of leukocytes (Total oxidative radical production) on rainbow trout injected with $\mathrm{PBS}$ and antigens. a: Control group, b: FKC, c: Ag-O. ${ }^{*} p<0.05$

Phagocytic index

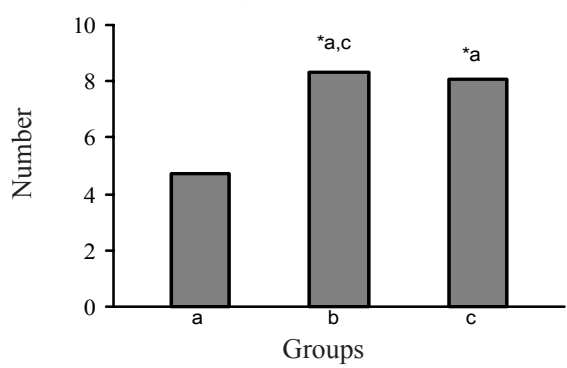

Fig. 5. Phagocytic index on rainbow trout injected with PBS and antigens. a: Control group, b: FKC, c: Ag-O $* p<0.05$
Total Ig

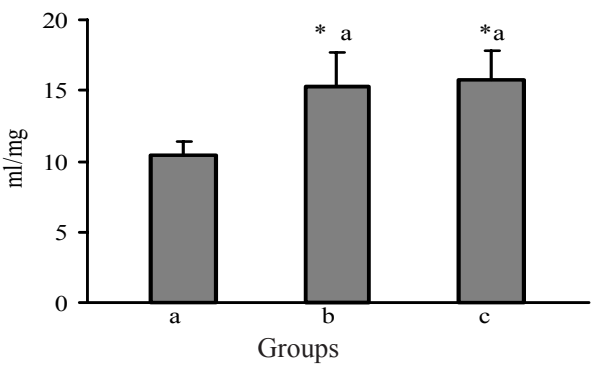

Fig. 2. Total Ig level of serum from rainbow trout injected with PBS and antigens. a: Control group, b: FKC, c: Ag-O. $* p<0.05$

\section{Phagocytic activity}

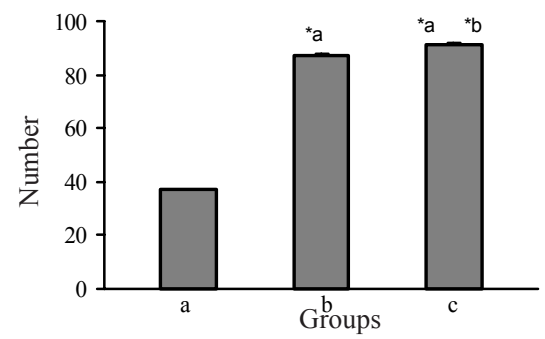

Fig. 4. Phagocytic activity on rainbow trout injected with PBS and antigens. a: Control group, b: FKC, c: Ag-O. ${ }^{*} p<0.05$

\section{Discussion}

Vaccination is an effective and economical means for the control and prevention of ERM in fishes. Bacterins with antigens of gram-negative organisms such as Vibrio anguillarum, $V$. ordalii, V. salmonicida and Yersinia ruckeri have been produced by broth fermentation and subsequent formalin inactivation (Stevenson 1997).

Fish have several types of phagocytic leukocytes, which are present in blood, the peritoneal cavity, and a variety of tissue locations. Phagocytosis and the production of oxygen-free radicals via the respiratory 
burst are important events in bactericidal pathways in fish, but the mechanisms are not well established. In our experiment, the phagocytic activity (PA) was markedly higher in FKC and $\mathrm{Ag}-\mathrm{O}$ than in the control group. A significant increase in the phagocytic index (PI) was observed in vaccinated fish 30 days immunization. These results confirmed the previous investigations with Vibrio damsela and Pasteurella piscicida (Santarem and Figueras 1995), Aeromonas hydrophila (Kozinska and Antychowicz 2001; Irianto et al. 2003), Aeromonas bestiarum (Kozinska and Guz 2004), Photobacterium damsela and Photobacterium damsela subsp. piscicida (Figueras et al. 1997).

Phagocytic functions appear to play a very important role in the protection of fish against pathogens (Rijkers 1982). It is known that lipopolysaccharide (LPS) preparations, also referred to as $\mathrm{O}$-antigen preparations, from fish pathogenic bacteria are effective in eliciting non-specific defence mechanisms in fish (Anderson and Jeney 1991; Anderson et al. 1991) and protection against Aeromonas salmonicida (Jeney and Anders on 1993). Vibrio damsela and Pasteurella piscida $\mathrm{O}$-antigen bacterins slightly increased phagocytic activity in spleen leukocytes and the specific immune response in turbot (Santarem and Figueras 1994). Jeney and Anderson (1993), working with rainbow trout (Oncorhynchus mykiss), showed that the injection of Yersinia ruckeri $\mathrm{O}$-antigen caused an increase in the number of neutrophils and monocytes in the peripheral blood and in the enhancement of non-specific defence mechanisms. Anderson et al. (1992) who found that rainbow trout injected with different concentrations of Yersinia ruckeri O-antigen showed higher phagocytic activity with increased doses of antigen. Moreover, Anders on et al. (1979) found higher variability in the number of plaque-forming cells when rainbow trout were injected with high doses of Yersinia ruckeri O-antigen.

Santarem and Figueras (1995) also reported that injections of turbot with Vibrio damsela and Pasteurella piscicida O-antigen were observed to have increased the concentration of plasma protein compared to saline-injected control turbot. In this study, the serum protein levels increased in fish immunized with Ag-O. Our results for this variable showed similarity to the results of the study of Santarem and Figueras (1995). The higher total protein levels found in the serum of bacterin-injected rainbow trout may be due to an increase in the production of non-specific defense factors. Elevations of levels of C-reactive protein, ceruloplasmin and lysozyme after immunization have been reported in carp and rainbow trout (Siwicki and Studnicka 1986; Murai et al. 1990; Rainger and Rowley 1993).

Teleosts mainly produce a class of immunoglobulin (Ig) which resembles mammalian IgM both in structure and physiological characteristics, being also present in soluble (secreted) and membrane-bound forms. The soluble form is secreted from B cells and is present in the blood and other fluids, where it plays a role as an immune effector molecule (Ross et al. 1998). Measurements of IgM levels in serum from several fish species have been surveyed and the results point to a range between 0.25 and $23.5 \mathrm{mg} / \mathrm{ml}$ (Israelson et al. 1991; Magnadottir and Gudmundsdottir, 1992; Uchida et al. 2000; Shelby et al. 2002). The results of our study are in agreement with the results of previous investigations.

The results of this study showed that all the antigen preparations injected are immunogenic, including an increase in both total Ig level and phagocytosis by total blood leukocytes after the immunization compared to control rainbow trout. Studies carried out on the immune response of immunized fish, such as $V$. anguillarum (Thuvander et al. 1987; Estevez et al. 1994) and V. salmonicida (Havarstein et al. 1990) against bacterial infectious, showed that the highest antibody levels are not directly related to protection (Cipriano and Ruppenthal 1987), but enhanced phagocytosis is very important to deal with the disease. In this study, total Ig levels in the FKC and Ag-O injected group were 
significantly different $(p<0.05)$ than in the control group. The results are similar to those obtained in previous studies (Anderson et al. 1979; Estevez et al. 1994; Kozinska and Guz 2004).

The results obtained in this study elucidate the relationship between the nature of antigens and protection. Our results may suggest that $\mathrm{FKC}$ and $\mathrm{O}$-antigen directly activate phagocytic activity, such as phagocytosis in rainbow trout. Further studies should be carried out on the response of specific and non-specific immune indicators in rainbow trout exposure to Yersinia ruckeri and other bacterial antigens.

\section{Imunitní odpověd' pstruha duhového (Oncorhynchus mykiss) na vybrané antigeny Yersinia ruckeri}

V této studii byl zkoumán vliv antigenů Yersinia ruckeri na imunitní systém pstruha duhového (Oncorhynchus mykiss). Pro pokus bylo použito 120 ryb o hmotnosti 20-30 g. Rybám byl intraperitoneálně podán $1 \mathrm{mg}$ směsi formalínem inaktivovaných bakteriálních buněk (FKC) a O - antigenu (AgO). Za 30 dní po imunizaci byla rybám v anestezii odebrána krev z ocasní žíly a ve vzorcích krve byla stanovena metabolická aktivita leukocytů (Nitroblue tetrazolium (NBT) activity), fagocytární aktivita (PA), fagocytární index (PI), celková bílkovina a celkový obsah imunoglobulinů séra (TIg). Stejná stanovení bez předchozí imunizace byla provedena u ryb v kontrolní skupině. Ve všech experimentálních skupinách bylo zjištěno zvýšení imunitních ukazatelů a objevily se průkazné rozdíly mezi kontrolou a experimentálními skupinami $(p<0.05)$. Metabolická aktivita leukocytů byla statisticky významně snížena $(p<0.05)$ během následujícího ošetření antigeny ve srovnání s kontrolní skupinou.

\section{References}

Anderson DP, Dixon OW, Lizzio EF 1991: In vivo to in vitro transfer of trout spleen sections for early analysis of the immune response. Fish Shellfish Immunol 1: 99-105

Anderson DP, Jeney G 1991: Response to in vitro and in vivo immunizations with Aeromonas salmonicida $\mathrm{O}$ antigen bacterins in rainbow trout (Oncorhynchus mykiss). Fish Shellfish Immunol 1: 251-260

Anderson DP, Moritamo T, Grooth R 1992: Neutrophil glass adherent, nitroblue tetrazolium assay gives early indication of immunization effectiveness in rainbow trout. Vet Immunol Immunopathol 30: 419-429

Anderson DP, Roberson BS, Dixon OW 1979: Cellular immune response in rainbow trout Salmo gairdneri Richardson to Yersinia ruckeri O-antigen monitored by the passive haemolytic plaque assay test. J Fish Dis 2: 169-178

Cipriano R, Rupphenthal T 1987: Immunization of salmonids against Yersinia ruckeri: significance of humoral immunity and cross protection between serotypes. J Wildl Dis 23: 545-550

Edwards PR, Ewing WH 1972: Identification of Enterobacteriaceae. Burgess Publishing Co., Minneapolis, pp. $21-47$

Estevez J, Leiro J, Toranzo AE, Barja JL, Ubeira FM 1994: Role of serum antibodies in protection of vaccinated turbot (Scophthalmus maximus) against vibriosis. Aquaculture 123: 197-204

Ewing EW, Ross AJ, Brenner DJ, Fanning GR 1978: Yersinia ruckeri sp. nov., the redmouth (RM) bacterium. Int J Syst Bacteriol 28: 37-44

Figueras A, Santarem MM, Novoa B 1997: Phagocytic activity of turbot (Scophthalmus maximus) leucocytes: opsonic effect of antibody and complement. Fish Shellfish Immunol 7: 621-624

Havarstein S, Endresen C, Hjeltnes B, Christie KE, Glette J 1990: Specific immunoglobulins in serum from Atlantic salmon, Salmo salar L., immunized with Vibrio salmonicida and infectious pancreatic necrosis virus. J Fish Dis 13: 101-111

Irianto A, Robertson PAW, Austin B 2003: Oral administration of formalin-inactivated cells of Aeromonas hydrophila A3-51 controls infection by atypical A. salmonicida in goldfish, Carassius auratus (L.). J Fish Dis 26: $117-120$

Israelsson O, Peterson A, Bengten E, Wiersma EJ, Andersson J, Gezelius G, Pilstrom L 1991: Immunoglobulin concentration in Atlantic cod, Gadus morhua L., serum and cross-reactivity between anti-cod antibodies and immunoglobulins from other species. J Fish Biol 39: 265-278

Jeney G and Anderson DP 1993: Enhanced immune response and protection in rainbow trout to Aeromonas salmonicida bacterin following prior immersion in immunostimulant. Fish Shellfish Immunol 3: 51-58 
Kozinska A, Antychowicz J 2001: Immune cross reactions in carp (Cyprinus carpio L.) after single or double immunization with Aeromonas hydrophila and Aeromonas sobria antigens. Bull Vet Inst Puławy 45: 43-7

Kozinska A, Guz L 2004: The effect of various Aeromonas bestiarum vaccines on non-specific immune parameters and protection of carp (Cyprinus carpio L.). Fish Shellfish Immunol 16: 437-445

Kwapinski JB 1965: Methods of serological research. John Wiley and Sons, New York, pp. 5-26

Magnadottir B, Gudmundsdottir BK 1992: A comparison of total and specific immunoglobulin levels in healthy Atlantic salmon (Salmo salar L.) and in salmon naturally infected with Aeromonas salmonicida subsp. achromogenes. Vet Immunol Immunopathol 32: 179-189

Murai H, Kodama H, Naiki M, Mikami M, Izama H 1990: Isolation and characterization of rainbow trout C-reactive protein. Dev Comp Immunol 14: 49-58

Rainger GE, Rowley AF 1993: Antibacterial activity in the serum and mucus of rainbow trout, Oncorhynchus mykiss, following immunization with Aeromonas salmonicida. Fish Shellfish Immunol 3: 475-482

Rijkers GT 1982: Non-lymphoid defense mechanisms in fish. Dev Comp Immunol 6: 1-13

Ross AJ, Rucker RR, Ewing WH 1966: Description of a bacterium associated with redmouth disease of rainbow trout. Can J Microbiol 12: 763-70

Ross DA, Wilson MR, Miller NW, Clem LW, Warr GW 1998: Evolutionary variation of immunoglobulin mu heavy chain RNA processing pathways: origins, effects, and implications. Immunol Rev 166: 143-151

Santarem MM, Figueras A 1994: Kinetics of phagocytic activity, plaque-forming cells and specific agglutinins of turbot Scophthalmus maximus L.) immunized with O-antigen of Vibrio damsela and Pasteurella piscicida. Fish Shellfish Immunol 4: 527-537

Santarem MM, Figueras A 1995: Leucocyte numbers and phagocytic activity in turbot (Scophthalmus maximus L.), following immunization with Vibrio damsela and Pasteurella piscicida O-antigen bacterins. Dis Aquat Org 23: 213-220

Shelby RA, Evans JJ, Klesius PH 2002: Isolation, purification, and molecular weight determination of serum immunoglobulin from gulf menhaden: development of enzyme-linked immunosorbent assay to assess serum immunoglobulin concentrations from Atlantic menhaden. J Aquat Anim Health 15: 254-262

Siwicki AK, Studnicka M 1986: Ceruloplasmin activity in carp (Cyprinus carpio L.). Bamidgeh 38 : 126-129

Siwicki AK, Anderson DP 1993: Immunostimulation in fish: measuring the effects of stimulants by serological and immunological methods. Abstract. Symposium on fish immunology. Lysekil, Sweden 1993.

Stevenson RMW 1997: Immunization with bacterial antigens: yersiniosis. In: Gudding R, Lillehaug A, Midtlyng P, Brown A (Eds): Fish vaccinology. Dev Biol Stand 90: 117-124

Tebbit GL, Erickson JD, van de Water RB 1981: Development and use of Yersinia ruckeri bacterins to control enteric redmouth disease. In: International symposium on fish biologies: serodiagnostics and vaccines. Dev Biol Stand 49: 395-401

Thuvander A, Hongslo T, Jansson E, Sundquist B 1987: Duration of protective immunity and antibody titres measured by ELISA after vaccination of rainbow trout, Salmo gairdneri Richardson, against vibriosis. J Fish Dis 10: 479-486

Tobback E, Decostere A, Hermans K, Haesebrouck F, Chiers K 2007: Yersinia ruckeri infections in salmonid fish. J Fish Dis 30: 257-268

Uchida D, Hirose H, Chang PK, Aranishi F, Hirayabu E, Mano N, Mitsuya T, Prayitno SB, Natori M 2000 : Characterization of Japanese eel immunoglobulin $\mathrm{M}$ and its level in serum. Comp Biochem Physiol B-Biochem Mol Biol 127: 525-532

Willumsen B 1989: Birds and wild fish as potential vectors of Yersinia ruckeri. J Fish Dis 12: 275-277 